\title{
Esencia y tradición poética en el teatro de Lope de Vega (reivindicación de David M. Gitlitz) ${ }^{1}$
}

\author{
Ramón Valdés Gázquez \\ Universitat Autònoma de Barcelona \\ ramonvaldesg@hotmail.com \\ Daniel Fernández Rodríguez \\ Université de Neuchâtel \\ daniel.fernandez.tejerina@gmail.com
}

Recepción: 07/07/2017, Aceptación: 11/07/2017, Publicación: 22/12/2017

\section{Resumen}

Frente a últimas tendencias y puntos de vista que han llegado a ser predominantes, en los que se insiste en el carácter preeminentemente espectacular del teatro de Lope y del Siglo de Oro, se recuerda su cualidad literaria y poética, a nuestro juicio igualmente esencial.

\section{Palabras clave}

teatro; poesía; espectáculo; Lope de Vega; Comedia nueva

\begin{abstract}
Poetic essence and tradition in Lope de Vega's theater

In contrast to the theories and visions that consider the Comedia Nueva and Lope de Vega's plays exclusively as performance, this paper recalls the works' poetic and literary dimension, which, from our point of view, is part of their essence, in the same way as the performative element.
\end{abstract}

\section{Keywords}

Theater; poetry; performance; Lope de Vega; Spanish Golden Age theater

1. Este artículo se beneficia de los fondos FEDER y de nuestra participación en el proyecto de investigación «Edición y estudio de 36 comedias de Lope de Vega» (FFI2015-66216-P), financiado por el Ministerio de Economía y Competitividad. 
Después de años, incluso siglos, de atención preponderante y casi excluyente a la historia del teatro en tanto que literatura, tal vez por reacción, y en consonancia con las consideraciones de Anne Ubersfeld en su clásico Lire le théatre, en nuestro ámbito de investigación últimamente se ha venido insistiendo y progresando muchísimo - y por fortuna- en el teatro en tanto que representación y espectáculo, tanto en investigaciones especializadas como en manuales de divulgación. Era una asignatura pendiente. Y sin duda hay que seguir avanzando por ese camino. Pero tal vez sea también oportuno, llegados a este punto, preguntarnos si, para reconocer el carácter espectacular, "performativo" - dirían algunos- del teatro, es necesario negar su carácter literario. Y también replantearnos si estamos considerando otros rasgos con el interés que merecen y si no debemos retomar algunos discursos que parecen haber quedado postergados u olvidados sin recibir suficiente atención ni desarrollo, como, por ejemplo, el de David M. Gitlitz en su libro de 1980 La estructura lírica del teatro de Lope de Vega. En realidad, claro está, digamos que nuestra reivindicación de Gitlitz podría serlo de toda una línea de atención al aspecto poético del teatro de Lope. Y ahí podríamos mencionar también, con Gitlitz, a Gustavo Umpierre, a Francisco Javier Díez de Revenga o a María Cruz García de Enterría. Pero Gitlitz nos interesa especialmente por su carácter más teórico y amplio y por haberse ocupado de la poesía (frente a los demás críticos mencionados, que se centraron en un solo género: la canción).

Anne Ubersfeld, tras iniciar su famoso ensayo sentenciando que el teatro no puede leerse, ${ }^{2}$ pues se pervierte su propia esencia, admitía pocas líneas después que a fin de cuentas hay que leerlo porque «la representación es algo fugaz, efímero y solo el texto permanece» (1989: 7). Pero como excelentemente apostilla Felipe Pedraza (2005: 77), y aquí es adonde queríamos llegar,

la clave no está solo en que el texto permanezca, sino en que en él se conserva en plenitud una realidad poética de altísimo rango, valiosa en sí misma. La experiencia nos demuestra que no existe razón para contraponer estas dos formas de vida de los textos dramáticos. En las tablas se nos ofrece mucho más, pero también mucho menos que en el libro.

2. La cita es recurrente y de sobra conocida: «No se puede leer el teatro. Esto es algo que muchos saben o creen saber. Lo saben, por desgracia, esos editores que solo publican las obras de lectura recomendada en las instituciones docentes. No lo ignoran los profesores [...] Los comediantes, los directores escénicos — que creen conocer el problema mejor que nadie- miran con cierto desdén y recelo todo tipo de estudios universitarios por considerarlos inútiles y soporíferos. Lo sabe también el simple lector...» (Ubersfeld 1989: 7). 
Esto es especialmente relevante y cierto en el caso de nuestra tradición dramática del Siglo de Oro, un teatro escrito «en poesía» o, si se prefiere, en verso y «lenguaje poético». Es un teatro en verso, sí, con todo lo que el verso implica: un uso discriminado del metro y de las estrofas, un ritmo, una musicalidad... Pero veremos además con frecuencia que ese teatro no solo es verso: es también poesía. Poesía que se formaliza a través de un cúmulo de figuras retóricas, comparaciones, metáforas, conceptos, agudezas, catacresis, símbolos, prosopopeyas, pero también mediante personajes más allá de su mera humanidad, diálogos ingeniosos, alusiones a tópicos, estéticas descripciones del amor, de los celos, de lugares u obras de arte, monólogos que trascienden la acción, la sintetizan, la simbolizan o la interrumpen. Es poesía, en fin, porque se configura y concibe como tal. Fulgurante poesía sobre las tablas, pasajera, intensa y fugaz. Y tras la representación, el espectador más ambicioso puede convertirse también en lector, y pasar de la fruición colectiva de la puesta en escena a la lectura individual de la obra, a un placer estético íntimo y pausado.

No es que lo digamos nosotros, Ubersfeld o el más autorizado, en términos de teatro español del Siglo de Oro, Felipe Pedraza: lo dijo el propio Lope. En varias ocasiones reivindicó las calidades poéticas de su teatro al hablar de la impresión, la representación y el espectáculo tramoyero, por ejemplo. Así, en el prólogo a la Parte XIV, en el que la figura alegórica del Teatro tomaba la palabra, mantenía: «quiero que [los lectores, antes espectadores] las gocen [mis comedias] con más espacio, dándoselas impresas». ${ }^{3} \mathrm{O}$ también Cervantes: "yo pienso darlas a la estampa, para que se vea de espacio lo que pasa apriesa y se disimula o no se entiende cuando las representan». ${ }^{4}$ La lectura del teatro, así pues, no es solo una mala solución para seguir disfrutando de una obra dramática ante la inevitable fugacidad del espectáculo, sino que implica una nueva y óptima posibilidad de acceso distinto y pausado al hecho literario. Y la consideración del teatro como literatura y objeto de lectura no es un constructo crítico sin base alguna, sino una realidad histórica que dejó múltiples evidencias — sustentadas en una demanda previa por parte del público-, desde la existencia de los impresos y manuscritos destinados a la lectura, hasta los testimonios en tal sentido expresados por los propios dramaturgos del xviI, quienes, fuera cual fuera su primera intención, vieron esas ventajas en el hecho de imprimir su teatro para la lectura.'

3. Tomamos la cita del prólogo a la Parte XIV, coordinada por José Enrique López Martínez (2015: 78).

4. El texto procede de la «Adjunta al Parnaso» en el Viaje del Parnaso, que citamos por la reciente edición de Montero Reguera y Romo Feito (2016: 135).

5. Es cierto que en 1616, en el momento del famoso pleito por la impresión de sus comedias, Lope sostuvo que las escribió solo para ser representadas y no impresas; sin embargo, frente a cierto relato que se ha establecido, en el que parecería que Lope solo quiere tomar el control de la impresión de sus comedias tardíamente cuando ve el éxito editorial y el fruto que daba su teatro, ya desde la publicación de El peregrino en su patria, en 1604, expresó un posible proyecto de imprimir sus comedias. Al respecto, véanse Dixon (1996: 47), Pontón (2013: 189-190 y 2017: 607-609) y Fernández Rodríguez (en prensa). 


\section{Teatro, poesía, literatura y lectura}

En un artículo admirable, como todo lo suyo, Victor Dixon afirma que el Fénix "destina sus obras a ser leídas, pero no como 'literatura'», pues, argumenta el eminente lopista, «Lope - y los que le editamos - publicamos sus comedias para lectores que, si no van a representarlas, deben ser los directores, actores y público de su propio teatro mental. No sabe Lire le théatre quien no intenta leerlas así, como un músico oye, leyéndola, una partitura» (1996: 58-59). Pese a llevar tanta razón, creemos que es posible matizar el veredicto del maestro.

Tal vez la perspectiva que adopta Dixon resulte aquí algo limitada, acaso porque, haciéndose eco de las reflexiones de Ubersfeld, juzga la experiencia de lectura del teatro áureo por parte de un lector del siglo XvII — su actitud frente al texto- en función de cómo un lector actual debería leer una obra de teatro contemporáneo. Y es que una de las particularidades de la Comedia Nueva, que la singulariza frente a otras tradiciones teatrales analizadas por Ubersfeld, es justamente — como afirma Pedraza - su carácter poético, no solo teatral. Y con ello no nos referimos únicamente a su condición 'lírica', sino a su emulación y competencia, asumida por parte de los dramaturgos, con las formas y tradiciones poéticas de la época, así como a los múltiples recursos poéticos que pone en juego. Sonetos, romances, décimas, metáforas, catacresis, canciones, versos prestados, glosas... no son meros adornos de la obra teatral, sino parte esencial de su condición, también, poética.

Desde luego, puede que no sepa leer un texto dramático quien no imagina su representación; ahora bien, igualmente, quien perciba el teatro del Siglo de Oro relegando u olvidando su cualidad poética pierde también parte de su esencia, tal y como fue concebida nada menos que por Lope de Vega. La lectura de la Comedia Nueva debería ser teatral y dramática, pero también literaria y poética. Y, de hecho, cuando Lope ofrecía sus comedias impresas a quien ya las había visto representadas, quería que el lector las volviera a imaginar, ahora sin las tiranías o pleitesías de la puesta en escena ya vista, ${ }^{6}$ y, tal vez, que las volviera a leer para apreciar con calma su poesía. La iniciativa de imprimir las comedias, y el éxito que estos impresos tuvieron, no son sino el rastro de esa dimensión literaria del teatro de Lope, y permiten su fruición no solo en el corral, sino tam-

6. En la Parte XII alude a las ventajas de la lectura sobre la percepción en el corral: «en tu aposento, donde las has de leer, nadie consentirás que te haga ruido, ni que te diga mal de lo que tú sabrás conocer, libre de los accidentes del señor que viene tarde, del representante que se yerra y de la mujer desagradable por fea y mal vestida, o por los ańos que ha frecuentado mis tablas, pues el poeta no la escribió con los que ella tiene, sino con los que tuvo en su imaginación, que fueron catorce o quince» (véase la cita en Laplana 2013: 49). En sentido parecido se había pronunciado ya Alonso López el Pinciano en su Philosophía Antigua Poética: «Y, si queréys examinar bien vn poema dramático, escudriñadle fuera de la representación, porq[ue] el actor bueno, de mala obra, hará buena, y al contrario, el malo, de buena, mala» (citamos por Carballo Picazo 1953: 525). 
bién en la lectura. ${ }^{7}$ Las dos caras de una misma pasión, al decir de Germán Vega García-Luengos (2010: 60), según demuestra a través del repaso de una serie de prólogos, censuras y otros testimonios (algunos de los cuales aquí retomamos).

Por ejemplo, la opinión de uno de los mejores lectores de Lope, Vicente Espinel, que imitó alguna que otra obra suya y concedió las aprobaciones de muchas de las Partes de comedias, como la de la Parte VII, en la que defiende una lectura puramente «intelectual» $\mathrm{O}$ «conceptual»:

Si hay permisión y es lícito representarse con los adornos, palabras y talle de una mujer hermosa y de un galán bien puesto y mejor hablado, ¿por qué no lo será que cada uno en su rincón pueda leellas, donde solo el pensamiento es el juez, sin los movimientos y acciones que alegran a los oyentes, donde es más poderosa la vista que el oído?

En efecto, tan lícita es una lectura que prefiera centrarse en recordar o imaginar una nueva puesta en escena como otra, la que propone Espinel, en la que la gestualidad de los actores y sus entradas y salidas no ocupen, entretengan ni despisten al pensamiento; una lectura, en definitiva, del teatro en tanto que literatura, realizada con la adecuada atención y con el suficiente detenimiento como para apreciar mejor la cualidad poética. Entiéndase que no pretendemos crear ni defender una dicotomía, sino que nos limitamos a atestiguar que esa defensa de la lectura del teatro en tanto que literatura se producía ya en la época, y nada menos que por un novelista y poeta de la talla de Vicente Espinel, amigo y maestro de Lope de Vega.

Sea como sea, imaginando o no actores y puestas en escena, el hecho es que a Lope, como decíamos, le pareció bien y oportuno que su teatro se ofreciera también impreso para la lectura. Una lectura que va a permitir entender, entre otras cosas, locuciones y conceptos, porque, aunque la comedia debe imitar el lenguaje llano que se habla cotidianamente y en la calle, admite Lope en el prólogo a la Parte $X V$ que a veces «se levanta el poeta [dramático] algo más de la imitación en alguna narración o soliloquio, o ya es éxtasis de la fértil vena o,

7. Según sentencia reciente de Gonzalo Pontón, «imprimir teatro es convertirlo en otra cosa: aquello que denominamos literatura» (2017: 560); tal vez nosotros preferiríamos expresarlo de otra manera: percibir, sancionar y promocionar su dimensión literaria. Y promocionar también la grandeza literaria de quienes lo escriben, que son aludidos, no casual, sino causalmente, como poetas. Sobre estas confluencias entre mundo escénico y editorial véase también la tesis doctoral de Guillermo Gómez (2015: 142ss), así como Alejandro García Reidy (2013). En lo que aquí nos atañe, parecen relevantes las siguientes palabras de Guillermo Gómez: «En estos años se presentan las comedias lopescas como el resultado de la pluma de un poeta y fueron vendidas en parte - siquiera para sortear una censura moral cada vez más estricta- como una muestra más de las formas líricas con las que la comedia compartía su forma externa, género que ya tenía un hueco bien asentado en la industria del libro» (2015: 148).

8. Las palabras de Espinel pueden leerse en la aprobación de la Parte VII, en la edición al cuidado de Enrico Di Pastena (2008: 61). 
por mayor parte, deleite del que escucha docto y bien intencionado agradece». ${ }^{9}$ Y en el prólogo dialogístico a la Parte XIV, el Teatro defiende que es mérito suyo, propio (ya que es el Teatro quien habla), portar las novedades poéticas:

No hablo de lo que me deben los oyentes, pues siempre querría deberles cortesía, que las nuevas frases, locuciones, donaires y otras infinitas diversidades de exornaciones en nuestra lengua, de mí se saben primero que de los libros [...] Soy estafeta brevísima de las sutiles y altas imaginaciones, que por la posta se las traigo al gusto por tan pequeño porte, y no contento de esto, también quiero que las gocen con más espacio, dándoselas impresas como las presento en esta Parte. ${ }^{10}$

Es interesante notar que estas observaciones son posteriores y muy cercanas a los pronunciamientos de Lope en torno a la nueva poesía y a la polémica de la Spongia y la Expostulatio Spongiae.

Pero reflexiones similares surgen en torno a otro tema: la imposición de la tramoya a la palabra. En el «Prólogo dialogístico» a la Parte XVI, el Teatro vuelve a tomar la palabra y cuestiona que todo el público esté en condiciones de entender «los versos, las figuras retóricas, los concetos y sentencias, las imitaciones y el grave o común estilo». ${ }^{11} \mathrm{Y}$ como escape a esa dificultad que podría espantar al público, y como atajo o trampa para mantenerlo atento y en el corral, se recurre a la espectacularidad de la tramoya y el gesto: "¿qué han de hacer los autores sino, convertidos en volatines, remitir a las tramoyas las comedias, y los poetas los concetos a los aros de cedazo?». ${ }^{12}$ Vélez de Guevara decía algo muy similar en el prólogo a El diablo cojuelo en 1641, donde alude al público, a los mosqueteros de la comedia, como "pescados de los estanques de los corrales, esperando, las bocas abiertas, el golpe del concepto por el oído y por la manotada del cómico, y no por el ingenio». ${ }^{13}$ Sea como fuere, y recapitulando, en estos fragmentos podemos ver cómo Lope se muestra consciente de que él utiliza en la comedia un lenguaje poético, incluso difícil en ocasiones para el espectador; un lenguaje que también le permite y exige un posicionamiento dentro de un contexto estrictamente poético. Porque, al fin y al cabo, como bien sabía Lope y como sabían los preceptistas de su tiempo, el teatro es poesía... poesía dramática.

Pero detengámonos... ¿El teatro es poesía dramática? Pensémoslo: hay obras con mayor intensidad poética, otras con menor. Con seguridad, siempre, inevitablemente, va a haber estructuras poéticas, metros, estrofas y un lenguaje con

9. La cita del prólogo a la Parte $X V$ está tomada de la edición que ha coordinado Luis Sánchez Laílla (2016: 77).

10. El texto procede de la edición de la Parte XIV coordinada por López Martínez (2015: 78).

11. Lope de Vega, "Prólogo dialogístico», en Decimasexta parte de las comedias de Lope de Vega Carpio, fol. Ir (ejemplar consultado: BNE, R 13867).

12. Lope de Vega, "Prólogo dialogístico», en Decimasexta parte de las comedias de Lope de Vega Carpio, fol. gv.

13. Luis Vélez de Guevara, El Diablo Cojuelo, p. 8. 
un menor o mayor grado de densidad poética. Y entre los momentos de mayor intensidad y densidad llegaremos a encontrar incluso comedias u obras donde el lenguaje y la estructura poética se imponen y condicionan su completo desarrollo o el de una parte importante. Pero también hay otros momentos, y otras obras, donde esa intensidad o densidad poética no se produce y tiene un fluir más puramente dramático o, digamos, menos poético. A bote pronto podemos recordar la comedia recién redescubierta, Mujeres y criados, y tal vez otras comedias urbanas.

\section{Perceptibilidad poética del lector y el público}

El lenguaje poético puede invadir cualquier pasaje. Por ofrecer un breve ejemplo de esos desarrollos poéticos básicos, comentaremos solamente un fragmento de $L a$ Arcadia, que ya recordaba Gitlitz, donde podemos observar un lenguaje poético que embellece un pasaje y amplifica los sentimientos del personaje, con una elaboración retórica, con anáforas, prosopopeyas y apóstrofes a los elementos naturales (las flores, las aves, los prados, los montes...) y a los pastores, y con un sentimiento amoroso que todo lo domina:

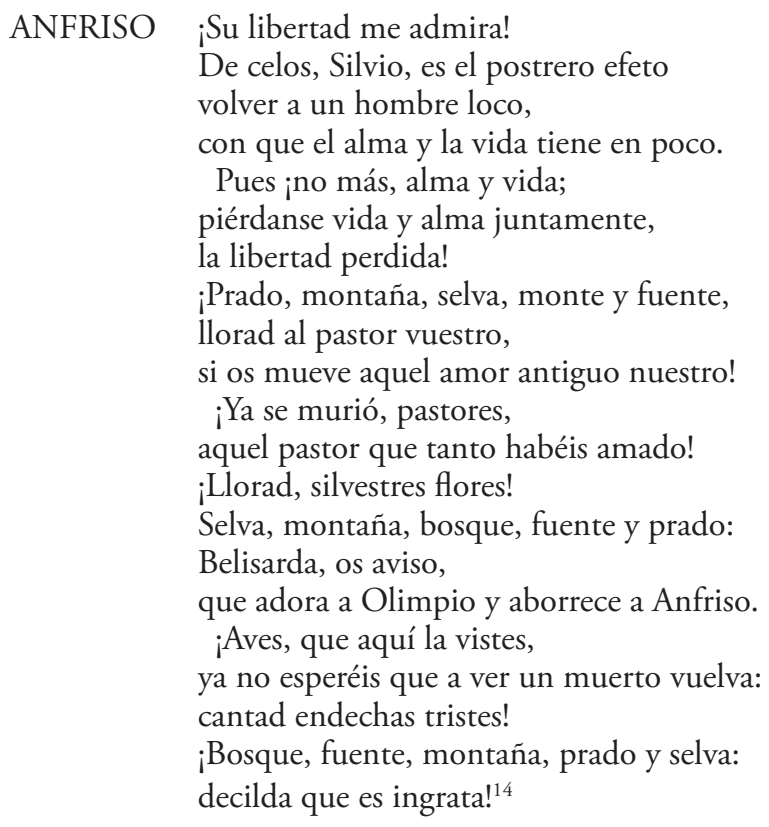

Por supuesto, es cierto, estamos en Arcadia, poblada por los personajes estilizados de la literatura pastoril, y en la lírica expresión del sentimiento del desamor.

14. Lope de Vega, La Arcadia, vv. 2724-2744. 
En otros pasajes la calidad poética puede resultar menos espectacular y estilizada, menos evidente y subrayada, más sutil, pero no por ello debemos pasarla por alto. Veamos ahora un fragmento de La gallarda toledana: don Diego, achacado por los celos, le ruega a su dama que no se deje halagar por cualquiera, porque la podrían juzgar por mujer ligera. Se dirige a sus ojos, que ya sabemos - pero no de manera tan generalizada como entonces- que son espejos del alma y emisores y receptores de espíritus amorosos, y que son también apelativo, por metonimia, de la propia amada:

\begin{tabular}{cl} 
DIEGO [...] & \multicolumn{1}{c}{ Pero vos entre los buenos } \\
amad, seńora, el mejor; & pues tenéis tanto valor, \\
& estimaos, ojos serenos; \\
& porque en la opinión que estáis \\
de hermosos y de atrativos, & más os querrán por esquivos \\
& que si a cuantos veis os dais. \\
BERNARDA & Si yo no doy ocasión, \\
¿qué importan sus pretensiones? & Con mirar dais ocasiones \\
DIEGO $\quad$ para tanta pretensión; \\
y si ser dueńo esperáis \\
de alguno, es bien que miréis \\
que menos dueños seréis \\
mientras más dueños tengáis. \\
Estad algún tiempo ajenos \\
de piedad, mirad con ira, \\
porque si cualquiera os mira \\
seréis tenidos en menos. ${ }^{15}$
\end{tabular}

Obsérvese la centralidad de los ojos como parte de un lenguaje poético que designa, por metonimia o sinécdoque, a la amada. Cuando se alude en apóstrofe a esos "ojos serenos", se establece la ecuación ojos = amada y se remite así a un lenguaje poético y a toda una tradición lírica. Además, en estos versos cobra gran importancia el término dueño, expresión que se remonta a la poesía trovadoresca, en la que el poeta, con una «actitud de sumisión y respeto que coincide con los postulados del feudalismo», solía llamar a su dama «midons, curiosa forma masculina, pues deriva de meus dominus» (Riquer 1975: 84). En este pasaje el dramaturgo utiliza conceptos que pertenecen a la tradición filográfica, pero entrelazados en un lenguaje que engañosamente podría parecer cotidiano, razón por la que podrían pasarnos lamentablemente desapercibidos.

Todo lo que venimos viendo invita a la reflexión: ¿̇cuántos momentos apelaban a la experiencia del público en tanto que lectores de poesía culta o co-

15. Lope de Vega, La gallarda toledana, vv. 1129-1148. 
nocedores y transmisores del romancero y de la lírica popular? Nuestro bagaje cultural es hoy muy distinto al del público de entonces. En gran medida, estamos mucho peor preparados para captar la poesía que empapa todo el teatro del Siglo de Oro. Es ahí donde aparece la figura del filólogo, que trata de subsanar esas carencias mediante notas aclaratorias al pie de página. Pero esas notas no figuran en muchas ediciones, y tampoco, desde luego, en las representaciones. Y por mucho que estén a nuestro alcance, la experiencia estética que nos brindan dista de ser la misma que la que tenía lugar en los corrales.

A la hora de anotar este pasaje de La gallarda toledana, comedia que tuvimos la suerte de editar para PROLOPE, además de aclarar el sentido de los versos y explicar estas referencias, creímos oportuno remitir al famoso verso de Gutierre de Cetina, «ojos claros, serenos». Nos parecía que así se podría acercar al lector actual a la experiencia poética que viviría el receptor de la época, quien recordaría tal vez el primer verso del celebrado madrigal del sevillano.

\section{Configuraciones poéticas}

Pero la poetización en el teatro de Lope puede ir mucho más allá de estos breves pasajes y no solo afectar al lenguaje, como bien observaba Gitlitz (1980): desde la configuración de tiradas de versos y escenas coherentes estilísticamente, hasta la configuración de actos e incluso de comedias enteras como si de poemas extensos se tratase a través de estribillos, glosas, metáforas continuadas o alegorías, simbologías coherentes y cohesionadas, que se traducen en lo que él llamó infralirismo, el dominio de un ambiente o trasfondo más poético que realista (¿podríamos llamarlo una suerte de «realismo poético» por analogía con el marbete "realismo mágico" y con lo que este comporta?) y que queda perfectamente ejemplificado, para que se entienda, en los recuerdos de la copla, en los augurios y en la composición completa, y especialmente del acto tercero, de El caballero de Olmedo. María Cruz García de Enterría (1965) y Francisco Javier Díez de Revenga (1983) demostraron que hay comedias enteras que se engendran en canciones y que, en cierto modo, se desarrollan como canciones.

Por otro lado, están los interludios líricos, algo así como paréntesis o fragmentos poéticos separables, desgajables de su contexto como poesía. Según Gitlitz, un interludio lírico debe reunir los siguientes requisitos: 1) tener un alto grado de autonomía poética, aunque puede referirse al argumento o algún personaje; 2) implicar un descanso en la acción y un lucimiento del poeta; 3) puede constituirse como vehículo para exponer propósitos temáticos (pues tiene la atención del público); y 4) puede utilizarse para cambiar el tono de una escena u ofrecer un contrapunto. Gitlitz distingue las siguientes clases: canciones —es algo que desarrollan ampliamente García de Enterría (1965), Umpierre 
(1975) y Díez de Revenga (1983)—, soliloquios, dúos, tríos y cuartetos, ${ }^{16}$ relaciones, pronunciamientos, descripciones líricas y lo que llama ensayos líricos. Todas estas variedades las estudia en su monografía.

Podemos matizar y completar las propuestas de Gitlitz: el interludio poético debe tener algún grado de autonomía, pero también estar bien justificado, motivado; puede ser un descanso de la acción o la tensión dramática, pero también amplificarla o intensificarla. Recuérdese la glosa del «sin mí, sin vos y sin Dios» de $E l$ castigo sin venganza, donde el excurso poético implica una profunda expresión de las tribulaciones del Conde Federico. Sin duda es un momento de clímax dramático perfectamente apoyado por - y en - un éxtasis poético. Sin embargo, a veces estos éxtasis, estas desviaciones de la realidad cotidiana del drama o la comedia a través de la poesía tienen un final muy diverso: son subrayadas por contraste, en una secuencia de clímax-anticlímax, a través de la parodia y el comentario distanciador, burlesco y ridiculizador. Ocurre así con esas declaraciones amorosas en que los galanes se elevan en éxtasis poético y amoroso hasta que son abatidos paródicamente por los graciosos; recuérdese el fragmento de El caballero de Olmedo:

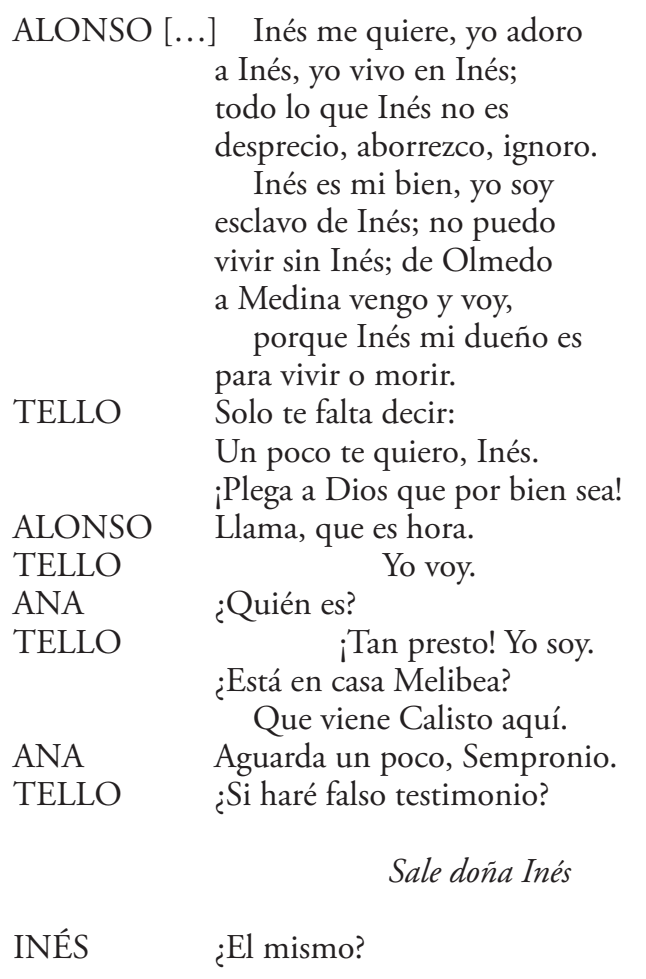

16. Fausta Antonucci (2017) analiza los sonetos en díptico y en tríptico en las comedias de Lope, estructuras complejas que asimismo cabría relacionar con estas categorías establecidas por Gitlitz (1980). 


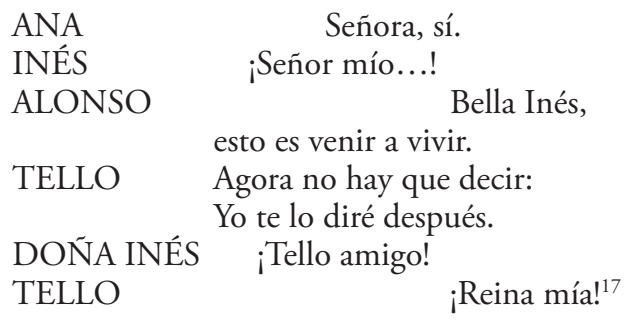

Resulta significativo que estos raptos donde el galán se deja llevar en éxtasis con su expresión amorosa a las cumbres del Parnaso sean resumidos con afán burlesco y paródico por los circunstantes como el «poetizar». ${ }^{18}$

Uno de los procedimientos por los que se hace patente la presencia de la poesía en la obra teatral consiste en la inclusión, aquí y allá, de citas y alusiones tanto de literatura popular como de literatura culta; citas y alusiones que hoy se nos pueden escapar, pero que sin duda Lope puso ahí con intención, y que previsiblemente el público de su época — culto o popular, en función de cada caso- podría identificar con mayor facilidad y rapidez que el actual. En el mismo fragmento de El caballero de Olmedo que acabamos de ver, la propia chanza de Tello, «un poco te quiero, Inés», es recuerdo de un cantar proverbializado — según anotó Francisco Rico y atestiguan Mergit Frenk y Alín y Barrio Alonso- - un cantar que seguía por cierto con el verso «yo te lo diré después», también jocoso en origen y que se cita asimismo poco después en la escena.

De hecho, debemos confesar que hace unas páginas hemos tendido una pequeña trampa al lector. Los versos de La gallarda toledana tal como los hemos transcrito más arriba se corresponden con un primer esbozo de edición. Quedaban algunos flecos sueltos, pero el texto estaba ya fijado, puntuado y anotado. Con todo, por aquel entonces aún no habíamos consultado el libro de José María Alín y María Begoña Barrio Alonso, Cancionero teatral de Lope de Vega (1997). La sorpresa llegó al pasar la vista por el índice onomástico y toparnos ahí con La gallarda toledana. Resulta que el fragmento citado escondía una sorpresa,

17. Lope de Vega, El caballero de Olmedo, vv. 988-1012.

18. Aduciremos únicamente otro caso, aunque cabrían muchísimos. En Lo cierto por lo dudoso, en típicos lances amorosos el galán empieza a lamentarse: «Pierde, / loca esperanza, el color; / y del luto de mi muerte / o de lo azul de mis celos / esmalta sus hojas verdes», y el gracioso Ramiro pierde la paciencia y dice: «No esmaltes hojas, por Dios, / ni poetices de esa suerte, / sino vamos al remedio» (vv. 1686-1692). Avanzada la comedia, vuelve a comentar los delirios poéticos de su amo: «¡Valiente, por Dios! ¡Ansí! / De lo que entiendo me agrado; / no aquello del ser sin ser, / por el ser del ser formado, / el ser del ser que no fuera, / de que el vulgo hace milagros, / y todos son disparates / en bernardinas fundados; / que si lo que se oye aprisa, / ello se oyera de espacio, / más de cuatro se corrieran / de lo que aquí celebraron» (vv. 2233-2244). 
una llamada por parte de Lope al saber poético del público de los corrales, que nuestros oídos modernos no habían detectado. Así quedaría editado finalmente el pasaje:

DIEGO [...] Pero vos entre los buenos amad, señora, el mejor; pues tenéis tanto valor, estimaos, ojos serenos;

porque en la opinión que estáis de hermosos y de atractivos, más os querrán por esquivos que si a cuantos veis os dais.

BERNARDA Si yo no doy ocasión, ¿qué importan sus pretensiones?

DIEGO Con mirar dais ocasiones para tanta pretensión;

y si ser dueño esperáis de alguno, es bien que miréis que menos dueños seréis mientras más dueños tengáis.

Estad algún tiempo ajenos de piedad, mirad con ira, porque si cualquiera os mira seréis tenidos en menos. ${ }^{19}$

Claro, de eso se trataba. Lope estaba apelando al acervo poético que ya no una parte selecta del público, sino posiblemente la mayor parte de los espectadores llevaba consigo a todos lados: al campo, a la mesa, a las noches en vela... Así que no quedó más remedio que relegar en nuestra nota al pie a Cetina y, en su lugar, aludir a la canción recuperada por Alín y Barrio Alonso, que se encuentra - con variantes — en otros textos de la época: «Estimaos, ojos serenos, / que si a todos favor dais, / cuantos más dueños tengáis, / seréis tenidos en menos» (1997: 180-181).

A decir verdad, muy poco nos permite acercarnos una nota aclaratoria como esta a la experiencia inmediata (no mediada por información adjunta al texto) del público de las comedias, que reconocería al instante los ecos de esa canción nada más oírla en la declaración de don Diego. Puede que algunos lectores los hayan percibido también, pero cabe pensar que, hoy en día, el público, en su mayor parte, no es tan ducho en la poesía del Siglo de Oro como para reconocer esos versos.

¿Cómo hay que interpretar la presencia de esta glosa? Ravasini, que ha estudiado la función de las glosas en el teatro del Siglo de Oro, concluye que estas permiten «desentrañar algún misterio, aclarar acaecimientos del pasado, o sobre

19. Lope de Vega, La gallarda toledana, vv. 1129-1148. 
todo poner de manifiesto las inquietudes y los sentimientos de algún protagonista» (Ravasini 1998: 1304), observación esta última que casa a la perfección con el caso de La gallarda toledana. Por otra parte, en nuestra opinión, esta glosa constituye una muestra más de que parte del espectáculo teatral consistía también en un ejercicio poético, en cierto modo un recital así percibido por el público, y valorado en función de la pericia del poeta para medirse con la tradición, evocar otros textos y, tal vez, también según la manera de destacar citas o determinados versos por parte de los actores. ${ }^{20} \mathrm{O}$ sea, nos hallamos ante un mecanismo puramente literario, que maneja los mismos códigos y presupone la misma relación entre emisor y receptor que cualquier otra expresión poética, por mucho que en esta ocasión la glosa de don Diego no se presente en papel sino en boca de un actor. Decía Francisco Rico, en una de las mejores definiciones del mester literario: «A decir verdad, en los trechos más largos de su recorrido, la literatura de Europa ha sido por definición un arte de conjugar reminiscencias, apuntar afinidades, incorporar matices, en un inacabable diálogo con los maestros y los cofrades» (1990: 280-281). Así ocurre en el teatro de Lope respecto a la tradición poética.

El uso de tantos recursos poéticos de todo tipo, alusiones, ecos, glosas o alegorías, tópicos, metáforas, incluso el empleo mismo de la polimetría o determinadas estrofas especialmente connotadas, funcionan a nuestro juicio como medio de elevación, de transustanciación de lo dramático en una categoría superior, en la que conviven lo dramático y lo poético. Una consecuencia inevitable (o mejor, buscada) del uso de versos conocidos por el público es que este, por un momento, trasciende la declaración de amor del galán — retomando nuestro ejemplo- y se deleita en el recuerdo catártico de unos versos que el poeta le acaba de avivar. La trama dramática avanza a lomos de la tradición poética.

El interludio poético a menudo se presenta dramáticamente, ya sea a través de un monólogo, ya sea por contraste entre lo que dicen unos personajes y otros (el clímax-anticlímax o parlamento elevado-respuesta paródica que hemos visto a propósito de El caballero de Olmedo), ya sea mediante una colaboración, como ocurre en este caso: para introducir su glosa, el poeta se sirve de un diálogo entre Diego y Bernarda y de la interrupción por parte de la dama, que secundan la integración de la poesía en la comedia. Bernarda interrumpe, pero a la vez invita al progreso y facilita la continuación de la glosa.

Pasemos, ahora, a analizar otro caso, correspondiente a El Argel fingido. Se trata, verdaderamente, de unos versos de gran intensidad lírica y dramática:

20. «La admiración expresada por Lope a propósito de algunas coplitas del siglo XV y de 'las agudezas de los poetas españoles antiguos', era sin duda compartida por muchos de sus contemporáneos, acostumbrados no sólo a detectar e identificar las citas, sino sobre todo a saborear su poder alusivo al ponerlas en relación con temas y motivos propios de los textos de origen» (Ravasini 1998: 1299). 


\section{Vase Piali y sale Leonido con cadena}

LEONIDO No pienses que estos hierros y cadena, en un alma que es firme y amorosa, menos que gloria son, porque es la pena, Flérida, para mi dulce y sabrosa.

En estas islas de desierta arena cualquier fruto de amor, cualquiera cosa le sabe al corazón, de angustias lleno, más que la fruta del cercado ajeno.

Las amenazas de tiranos bravos poco te han ofendido, dulce esposa, que me pareces con aquesos clavos más blanca que la leche y más hermosa. Pues somos con igual fortuna esclavos, vivamos esta cárcel tenebrosa, que es mejor, con tu cielo tan sereno, que el prado por abril de flores lleno.

ROSARDO Aunque cumples con ser tan firme amante, no cantas bien en tu prisión, Leonido.

LEONIDO Canta, señor, el solo caminante y el pastor en los montes escondido; canta sobre la mar el navegante, y al son de la cadena en que está asido canta también el preso; y deste modo canto mi pena yo, que lo soy todo.

\begin{tabular}{ll} 
LEONIDO & \multicolumn{1}{c}{\begin{tabular}{c}
\multicolumn{1}{c}{ Y la tengo } \\
por galardón y bienaventuranza, \\
que sin mí estoy; mis penas entretengo, \\
que hasta la muerte dará la esperanza. \\
Ya por mi mal, Leonido, a pensar vengo \\
que en todos los del mundo habrá mudanza.
\end{tabular}} \\
$\begin{array}{ll}\text { A Flérida olvidé. } \\
\text { LEONIDO }\end{array}$ \\
¿Cómo es posible?
\end{tabular}

El parlamento rezuma un patetismo que por fuerza debía de mover los afectos del público y ser uno de los momentos álgidos de la interpretación y puesta en escena. Fijémonos en la acotación: "sale Leonido con cadena». El actor que interpretara al cautivo debía irrumpir en el escenario arrastrando las cadenas, precedido quizá por el ruido de estas sobre las tablas. Esa entrada debía de causar una honda conmoción, pues hasta ese momento Leonido no había llevado atadura alguna. Incluso el propio Rosardo, su captor, no puede

21. Lope de Vega, El Argel fingido y renegado de amor, vv. 2369-2400. 
por menos que sorprenderse ante las trazas del desdichado: « $i$ Cadena te pusieron?». Y todo ello, remozado con unos versos procedentes de la Égloga III de Garcilaso, según ha puesto de relieve el editor de la comedia, Guillermo Serés. Sin duda la aparición de Leonido ligado a una cadena, lamentando su desventura, dando voz a Garcilaso e interpelando a su amada Flérida es uno de los momentos más memorables de la pieza. ${ }^{22}$ Por su poesía, por la autoridad poética que invoca la cita, por su puesta en escena, por la emoción que una y otra, entreveradas, transmiten. La escena cumbre dramática se acompaña de una cumbre poética.

Pero sigamos. La comedia no tiene nada que ver con un ambiente pastoril, y, sin embargo, la escena aludida aparece asaeteada desde todos los flancos por referencias literarias y poéticas. Según observa Serés, «Leonido ha asumido características de los cuatro arquetipos amorosos: peregrino, o 'caminante', de amor; 'pastor' bucólico (hace suyos los versos de Garcilaso); 'navegante' y náufrago de amor; y, en fin, 'preso' en los dos sentidos: preso de amor y prisionero por amor» (2009: 685). Centrémonos, ahora, en la veta pastoril, la que arranca de la égloga tercera de Garcilaso.

Lo primero que hay que advertir es que, en efecto, el personaje al que interpela Leonido se llama Flérida, un nombre un tanto extraño en el teatro de Lope. Según revela una búsqueda en la base de datos Artelope, el dramaturgo solo lo empleó en otras dos comedias, muy próximas cronológicamente: Elmármolde Felisardo (¿1594-1598?) y La mocedad de Roldán (1599-1603). En El mármol de Felisardo es una pastora la que lleva ese nombre, mientras que en La mocedad de Roldán lo adopta la infanta de Francia para ocultar su identidad y vivir como una villana. Así pues, en las tres piezas el nombre de Flérida arrastra, de un modo u otro, tintes rústicos y pastoriles.

El Argel fingido suele fecharse en 1599, y las otras dos obras fueron escritas, grosso modo, en el segundo lustro de los años noventa. Por aquel entonces, concretamente en 1598, Lope dio a las prensas su Arcadia, cuya hechura delata un profundo conocimiento de la tradición pastoril y de las églogas de Garcilaso, según se esperaba de un escritor con tantos mimbres, tablas y oficio como el Fénix, y según nos ilustra en su excelente edición Antonio Sánchez Jiménez (2012). ${ }^{23}$ Por consiguiente, creemos pisar sobre seguro al afirmar que la coincidencia o cercanía temporal entre la asunción, como lector, de la Flérida garcilasiana por parte de Lope y la irrupción, como personaje, de una pastora o villana fingida con ese mismo nombre en El mármol de Felisardo y La mocedad de Roldán parece todo menos una casualidad. Así lo corrobora el hecho de que justo al año siguiente de publicar la Arcadia, Lope decida homenajear al poeta toledano, uno de sus modelos, en El Argel fingido. Ahora bien,

22. Así lo había notado el propio Serés (2007) en un brillante artículo.

23. Además de las notas al texto, véanse las páginas 29-30 del prólogo. 
a diferencia de lo que ocurre en esas dos comedias, esta otra Flérida no tiene nada de pastora ni de villana idealizada. Es una dama cualquiera, monda y lironda, como las que campan a sus anchas en tantas otras comedias. ¿Por qué, entonces, llamarla Flérida?

La hipótesis que planteamos es que Lope tenía ya en mente la escena, memorable, que acabamos de leer cuando concibe o traza el plan en prosa de su comedia y bautiza a su dama. Una escena donde se entrecruzan tantos tópicos y tradiciones literarias, que destaca además por ser una de las más efectistas desde el punto de vista escénico (muy representativa, por lo tanto, de lo que entendemos que puede llegar a ser una comedia de Lope: teatro y poesía), bien pudo ser ideada desde el inicio. La concepción de esa escena en el magín de Lope, en la cual la cita de Garcilaso formaba parte esencial, arrastraría consigo $a b$ initio el nombre de Flérida, que le tocaría en suerte a una mujer que nada tenía de pastora o rústica idealizada —al contrario que las otras dos Fléridas lopescas-, pero que permitiría así que la transfiguración de Leonido en los cuatro arquetipos amorosos y la cita de los versos garcilasianos fueran en feliz conjunción mucho más claras y efectivas. En cuanto al proceso genético que proponemos, no es muy distinto del que observan García de Enterría y Díez de Revenga en la concepción de comedias enteras a partir de estribillos, cantares y seguidillas.

Así pues, la poesía antecede y condiciona decisiones puramente teatrales como la elección onomástica para uno de los principales personajes del elenco y la naturaleza del mismo diálogo dramático. A modo de apoyo de esta interpretación, pero también como caso complementario y compendio de cuanto tratamos de defender, se pueden retomar las palabras de un excelente conocedor de Lope en todas sus facetas: la dramática, la poética, la vital. Felipe Pedraza, basándose en la vida y la obra del Fénix, como le gusta hacer al catedrático - y hombre de teatro- afincado en La Mancha, alega que los sonetos «se convertían fácilmente en un momento de la función que quedaba en el recuerdo" (2016: 527). Lo mismo vale, creemos, para otros intermedios líricos, y desde luego para el que nos ocupa: ¿cómo no iba a quedar grabada en la mente del espectador la entrada de Leonido encadenado citando a Garcilaso e interpelando a su amada Flérida? Pues bien valía la pena entonces supeditar a ese y a otros interludios líricos otras muchas facetas teatrales de esta y de centenares de comedias.

Conviene recordar que también podemos encontrar citas no declaradas de poetas cultos contemporáneos, incluso en otras lenguas, como Camoens en $\mathrm{La}$ octava maravilla (2662-2687), donde Lope recoge no solo el estribillo o mote tradicional, sino también la volta o glosa de Camoens en su cantiga. Por otro lado, la cita o inclusión de esta cantiga es tremendamente oportuna, pues $L a$ octava maravilla es una comedia de celebración de la monarquía y del imperio español en un momento en que Portugal pertenece a la corona española, como las colonias asiáticas donde se desarrolla parte de la trama. 


\section{Géneros poéticos}

Pero conviene estar atentos, porque si pasamos del terreno de la cita al de la canción y la glosa, estamos ya pisando el terreno del género poético. Así, ya no se trata solo del lenguaje y estilo poético de determinados pasajes, o del uso de citas poéticas, sino de la presencia de géneros literarios diferenciados y diferenciables; por tanto, ya no se trata de fragmentos desgajables, sino que, en cierto modo, podríamos hablar de piezas poéticas que, insertas en el drama, pueden conservar su entidad e identidad genérica poética, cuyo secreto de composición e inclusión en la obra literaria superior, en la obra dramática, está en encontrar el equilibrio y grado adecuado de autonomía como para poder alcanzar luego, incluso, la independencia. Con ese grado de autonomía y potencial independencia, por supuesto, además de contar las canciones tan bien estudiadas ya por García de Enterría, Díez de Revenga o Alín y Barrio Alonso, es necesario tener muy presente el soneto, pero también las relaciones, la sátira, ciertos motivos poéticos... Nos fijaremos en unos pocos casos.

El soneto es quizá la única combinación estrófico-métrica presente en las comedias que funciona en cuanto género y pieza completa más que como forma métrica: no podemos hablar de series de sonetos como lo hacemos con las series de redondillas, décimas, octavas reales, tercetos encadenados, incluso liras o silvas, sino, como mucho, de sonetos en díptico o en tríptico (según observa Fausta Antonucci 2017), uno tras otro, pero sin configurar series como sí ocurre con las décimas. Los sonetos resultan claves en la comedia: no es de extrañar, pues se trata de una estrofa que es a la vez forma y género de una fortísima entidad en el Siglo de Oro, como bien vio Claudio Guillén (1988). Pondremos un único ejemplo de soneto que implica una composición poética perfectamente desgajable. Entiéndase: una vez desgajado, el soneto no pierde sentido, aunque en el marco de la obra esté perfectamente motivado, ya que no es de ningún modo un interludio inconexo con su contexto.

BLANCA Blando sueño amoroso, dulce sueño, cubre mis ojos porque vaya a verte, o ya como la imagen de la muerte, o porque viva un término pequeño.

Con imaginaciones me despeño a tanta pena y a dolor tan fuerte que solo mi descanso es ofrecerte estos sentidos, de quien eres dueño.

Ven, sueño, ven revuelto en aura mansa a entretener mi mal, a suspenderme, pues en tus brazos su rigor amansa.

Ven, sueńo, a remediarme y defenderme, que un triste, cuando sueńa que descansa, por lo menos descansa mientras duerme. ${ }^{24}$

24. Lope de Vega, La batalla del honor, vv. 2243-2256. 
Lo traemos a colación porque elabora un motivo tópico, una invocación al sueño, con una amplia tradición poética clásica y contemporánea, de modo que a la vez es claramente identificable como composición completa y autosuficiente. No nos podemos entretener ahora en un comentario del soneto, pero sí diremos que se inserta en una tradición en la que participan, en este caso concreto, Virgilio, Horacio, Estacio, Pontano, Giovanni della Casa, fray Luis, la Canción I del primer libro de los Versos de Fernando de Herrera (1619) — acaso el referente más próximo y directo-, Góngora con un soneto y Quevedo con una silva.. ${ }^{25}$ Hasta tal punto es desgajable, autónomo y, finalmente, independiente - $y$ este es el último motivo, también relevante, por el que lo aducimos-, que fue recogido por Antonio Carreño en su edición de las Rimas humanas y otros versos, añadido según el procedimiento del propio Lope, que había ido recogiendo en sus ediciones de las Rimas sonetos procedentes de las comedias, a veces retocados y mejorados. Este legítimo proceder, tanto de Lope como de Carreño, es un síntoma más y una prueba de la compatibilidad y doble esencia dramática y poética de estas obras. Por supuesto, en este terreno es necesario también recordar las comedias vertebradas por una serie de sonetos, al estilo de El perro del hortelano. ${ }^{26}$

Es por ello que consideramos, como decíamos, que se puede hablar de la comedia como palestra poética donde se ofrece una suerte de recital, de exhibición literaria. Una palestra donde la poesía se levanta y pone en pie conservando su identidad dentro del drama. Y en ese contexto cabe entender perfectamente, creemos, los sonetos en díptico a los que alude Fausta Antonucci. También los sonetos en díptico implican una variedad genérica con entidad dentro de la tradición poética: Antonucci mencionaba, citando a Alatorre, los partimens y tençós trovadorescos, los debates cancioneriles, y, entre los contemporáneos de Lope, a Bartolomé Leonardo de Argensola.

Pero sigamos con otros géneros reconocibles y con entidad poética que se «incrustan» en la comedia, como son las relaciones. Al poco de iniciarse El maestro de danzar, la curiosidad del caballero Aldemaro por saber cómo terminaron unos festejos es la excusa urdida por Lope para insertar una relación en romance de más de cien versos en la que su primo Ricaredo pasa revista, con todo lujo de detalles, a las justas, libreas, emblemas, juegos de cañas, etc.

$\begin{array}{lll}\text { ALDEMARO } & \text { ¿Qué hubo? } & \\ \text { RICAREDO } & \text { Fue largo cuento. } \\ \text { ALDEMARO } & \text { ¿Cómo? }\end{array}$

25. Véase la nota correspondiente a la edición de La batalla del honor.

26. Felipe Pedraza dirigió una tesina a Raquel Nieto (2010) sobre las «comedias sonetiles», aquellas que contienen cinco o más sonetos, en las cuales «los paréntesis líricos acaban convirtiéndose en elementos vertebradores de la acción dramática, pues sintetizan magistralmente los contradictorios pasos del proceso sicológico de los agonistas», en palabras de Pedraza (2016: 526) en su recentísima y muy meritoria edición del Arte nuevo escrita junto a Pedro Conde. 


$\begin{array}{lc}\text { RICAREDO } & \text { Premios y invención. } \\ \text { ALDEMARO } & \text { ¿De fuera? } \\ \text { RICAREDO } & \text { Los más lo son. } \\ \text { ALDEMARO } & \text { ¿Quién eran? } \\ \text { RICAREDO } & \text { Escucha atento. }{ }^{27}\end{array}$

Acto seguido da comienzo una típica relación de sucesos, género poético muy popular por aquel entonces, que Lope incrusta para deleite de los espectadores. Con todo, es cierto que el dramaturgo se ha esforzado por ensamblarla bien con el argumento: en primer lugar, el torneo descrito se celebra con motivo de las bodas de Tebano y Feliciana, matrimonio mal avenido que dará mucho juego en la comedia, gracias a las burlas de que es objeto el primero y a los ardientes deseos que ella siente por su maestro de danzar. Además, durante la relación se describe al joven Bandalino, pretendiente de Florela - la cual deslumbra con su belleza a todos los participantes - y rival amoroso de Aldemaro a lo largo de la pieza.

No ha sido posible dar con una fuente histórica concreta, pero es importante señalar que el dramaturgo aprovecha la relación para ensalzar la casa de Alba. Cuando remató la pieza, en 1594, Lope estaba al servicio de Antonio Álvarez de Toledo, quinto duque de Alba, razón que debió de inducirlo a ponderar la destacada participación en el torneo del padre y del hermanastro - ambos fallecidos, este último poco antes de la escritura de la comedia- de su señor, que reciben los premios de mejor hombre de armas y de mejor galán, respectivamente.

En Viuda, casada y doncella, Lope se vale de una relación como recurso para anunciar el naufragio de la nave en la que viajaba el protagonista, Feliciano. Se titula "Relación de los que han muerto / en el naval desconcierto / de la nao llamada Flor». ${ }^{28}$ No hemos podido averiguar si tiene algún fundamento histórico, pero, en cualquier caso, Lope se esfuerza por pintarla como tal, dotando a la escena de una gran verosimilitud. Así comienza:

$$
\begin{aligned}
& \text { Caballeros y soldados } \\
& \text { que se ahogaron y perdieron, } \\
& \text { los que aquí se siguen fueron, } \\
& \text { porque estaban alistados: } \\
& \text { Guillermo, Fidardo, Antonio, } \\
& \text { Pedro Enríquez Lomelín, } \\
& \text { Sancho Ordóńez, don Martín, } \\
& \text { Lope de Zúñiga, Andronio }{ }^{29}[. . .]
\end{aligned}
$$


En esta relación, Lope acumula hasta una treintena de nombres propios (muchos de ellos con sus respectivos apellidos), con el fin de imitar la incertidumbre que debía de suscitar la lectura de estas listas funestas, en las que se hacinaban las víctimas del mar y sus peligros (naufragios, corsarios, etc.). Se trataba sin duda de un fenómeno frecuente en aquella Valencia que tan bien conoció el Fénix, y en la que se desarrolla la acción de Viuda, casada y doncella.

Es obvio que estas relaciones cumplen con los criterios y rasgos de una relación de actos de la época, de aquellas relaciones poéticas en romance que se imprimían en pliegos sueltos o incluso en pequeños libros, género laudatorio que el propio Lope cultivó en las Fiestas de Denia a Filipo III. Se nos ocurren otras similares en comedias como La octava maravilla (con dos: una écfrasis del monasterio de El Escorial; otra de la nobleza de España), El amante agradecido, El blasón de los Chaves de Villalba. En El amante agradecido se trata en realidad de una écfrasis, una descripción del famoso túmulo que se erigió en Sevilla a Felipe II. ${ }^{30}$ Lo curioso es que, de modo sistemático, a pesar de haber buscado fuentes para anotar y documentar estas relaciones en nuestras ediciones de Prolope, por lo común no hemos logrado encontrarlas. No podemos demostrar que sean relaciones escritas y publicadas previamente. ¿Podemos plantearnos que fueran compuestas ex profeso por Lope para estas comedias, y que, entonces, las propias comedias, en esos versos y representadas ante las masas, asumieran el papel de las relaciones poéticas de actos públicos, género reconocidísimo en la época? ¿Y que Lope, aspirante a cronista, asumiera el deber de incluirlas o, mejor, crearlas en sus comedias?

Y una última cuestión, también significativa, respecto a las relaciones en tanto que género poético reconocible como tal e incrustado en la comedia, cuestión de la que se ha ocupado Maria Grazia Profeti (2012). No resulta nada desdeńable el dato de la aparición y auge entre 1675 y 1825 del género editorial de los pliegos sueltos poéticos denominados relaciones de comedias, que recogieron, entre otros, fragmentos de comedias que eran precisamente relaciones. ${ }^{31}$ Eso demuestra, como en el caso del soneto, su entidad poética, su potencial independencia de la comedia y el interés que despertaba en el público. Aunque la representatividad de Lope es muy exigua porque este género editorial surge en un momento de absoluto ocaso de su gloria, su nacimiento nos parece significativo y reseñable, así como el hecho de que también recoja lo que propiamente llamamos relaciones.

En cuanto interludios poéticos claramente desgajables y que se relacionan con tradiciones y motivos de muy clara ascendencia, aportaremos solo otro par de ejemplos. Ambos, curiosamente, surgidos de similar contexto. En dos dramas de honor en algunos aspectos paralelos, La batalla del honor (1608) y La locura por la honra (1610-1612), un personaje se vuelve loco ante las presiones

30. Lope de Vega, El amante agradecido, vv. 1527 y ss.

31. Acerca de este género editorial y literario pueden consultarse Cortés Hernández (2008), González Cañal (2010) y González (2011). 
y obligaciones del pundonor y el deber de renunciar a su venganza por respeto a la vida del soberano o de su heredero. En La batalla del honor (vv. 26542788) asistimos a una suerte de alucinación alegórica, una psicomaquia que el personaje agredido y loco va explicando a su interlocutor. Poseído, nos dice que está presenciando una batalla, la batalla del honor, donde a su lado luchan el Sargento Mayor Ilustre Nobleza, los soldados Recelos, la Fama por atambor y el capitán de Campaña Honrosa Defensa, Honestidad, Satisfacción, Celos, Vergüenza, etc. La escena implica un clímax dramático y la elevación del sentimiento trágico y patético. Lope retoma técnicas y motivos procedentes de las clásicas psicomaquias, de Prudencio, pero también presentes en la canción IV de Garcilaso, en autos sacramentales, en el teatro jesuítico, en Sánchez de Badajoz, Cervantes... ${ }^{32} \mathrm{Y}$ en cambio, en La locura por la honra, las alucinaciones del proceso de locura producen un interludio clarísimamente satírico desarrollado en tres fases con ecos de Luciano, Quevedo y Ariosto. ${ }^{33}$ Mientras que el de La batalla del honor contribuye al clímax trágico, en La locura por la honra se produce un anticlímax, una interrupción o suspensión del sentimiento trágico que predominaba hasta el momento, una especie de distensión que concuerda con la tradición más clásica, la que intercalaba el satiricón en la tetralogía trágica.

\section{La comedia como palestra poética}

Hemos aludido varias veces a la comedia como palestra poética. Lo es también en tanto que lugar para el debate y la exposición de principios poéticos. Ocurre así por ejemplo en el soneto "La calidad elementar resiste», recogido en La dama boba, el cual, según Marco Presotto,

es algo completamente nuevo en la producción de Lope, parece la prueba evidente de una participación profunda, emotiva y radical en el momento de renovación poética, y en esos años ha llegado a maduración en el campo literario la conciencia de la urgencia de una reflexión sobre el sentido mismo de la poesía como expresión vital. La composición expresa las teorías neoplatónicas que permitían a Lope juntar el amor loco con el buen amor, lo profano con lo divino: ofrecían una vía de salida, una explicación, una justificación; daban coherencia a sus múltiples pasiones como hombre y como poeta. (Presotto 2013: 209)

Del mismo modo que La dama boba fue una obra clave para Lope, y por eso la incluyó en su Parte IX apenas tomó el control de la publicación de sus comedias, no es de extrańar, concluye Presotto, que recogiera de nuevo el soneto «en sus obras más elitistas, La Filomena y La Circe, y acudiera a él en el momento de defender toda una concepción del lenguaje poético entendido como forma de la expresión

32. Véanse Fothergill-Payne (1980) y Hack (2009).

33. Un detallado estudio en Valdés (2004: 137-150). 
de una entera visión de la armonía universal» (2013: 214). El soneto, en perfecta coherencia con la obra, sintetiza la postura ideológica que expresa a través de ella, y la trasciende, porque también sintetiza un punto vital —el del Lope de 1613, en plena crisis espiritual por acontecimientos familiares y opciones vitales- $y$, por tratarse de Lope, implica también un posicionamiento estético. Durante mucho tiempo este soneto se relacionó con las polémicas gongorinas. En cambio, Presotto entiende que está alejado del primer momento de estas, aunque es cierto que luego adquirió el rango de credo y posicionamiento poético y estético dentro de las disputas literarias. Eso sí, surgió desde el propio interior. El lugar elegido para esta expresión fue una comedia, y dentro de la comedia, el soneto; la comedia completa, coherente con ese soneto, es y se convierte también, como el propio soneto, exento e independiente, en un punto de reivindicación poética y personal de Lope de Vega.

El tema del gongorismo en Lope, y concretamente en su teatro, fue tratado por Carmelo Samonà (1964), Hilborn (1971), Quintero (1991) y Melchora Romanos (2010). Si el lenguaje poético invade la comedia, evidentemente, también las últimas tendencias y novedades poéticas llegan al teatro, que, como decía Lope, las transmite y hace llegar al público. Un solo fragmento de $L a$ vengadora de las mujeres puede servir como ejemplo, y a la vez ilustrará el género de la relación. La comedia fue escrita precisamente en los años de mayor fulgor de las polémicas gongorinas, y en ella, paradójicamente, como ya sabemos, se puede percibir esa huella del gongorismo:

\begin{tabular}{|c|c|}
\hline LAURA & $\begin{array}{l}\text { Después, Lisardo, sabrás } \\
\text { cuánto se encubre en los buenos. } \\
\text { Oye agora lo que es menos, } \\
\text { mientras que sabes lo más. } \\
\text { Después que Arnaldo en el supremo asiento } \\
\text { ocupó su lugar, y yo en el mío, } \\
\text { con alas de oro por el manso viento, } \\
\text { la fama de que soy el precio envío } \\
\text { al aplauso templado el instrumento, } \\
\text { entró Alejandro con gallardo brío: } \\
\text { Alejandro, gran duque de Ferrara, } \\
\text { que el sol a verle en su balcón se para. } \\
\text { Con calzas verdes, armas blancas lleva, } \\
\text { pendiente al hombro un verde manto escuro } \\
\text { con mil hiedras de aljófar, labor nueva, } \\
\text { de quien, si álamo no, firme fue muro } \\
\text { con los padrinos, y el aplauso eleva } \\
\text { el vulgo, ya de su valor seguro, } \\
\text { en un caballo, de los vientos pluma, } \\
\text { de la clin al codón rico de espuma. }\end{array}$ \\
\hline
\end{tabular}

34. Lope de Vega, La vengadora de las mujeres, vv. 2039-2058. 
En sus escaramuzas con Góngora, claro, Lope también utilizó la comedia como lugar para el combate de las novedades y modas poéticas, y desde fechas bien tempranas. En este sentido Santiago Restrepo (en prensa) acaba de demostrar fehacientemente que en El caballero del milagro se puede encontrar uno de los rastros tempranos de la rivalidad entre ambos poetas. Se trata de una parodia de los altisonantes esdrújulos. El pasaje en el que se produce no deja lugar a dudas: en una escena de comicidad absoluta, el pícaro Luzmán, con sus halagos y retórica, engańará por tercera vez a unos personajes que, estando ya prevenidos y habiendo sido ya engañados, de nuevo caerán ante el irresistible poder seductor de su labia:

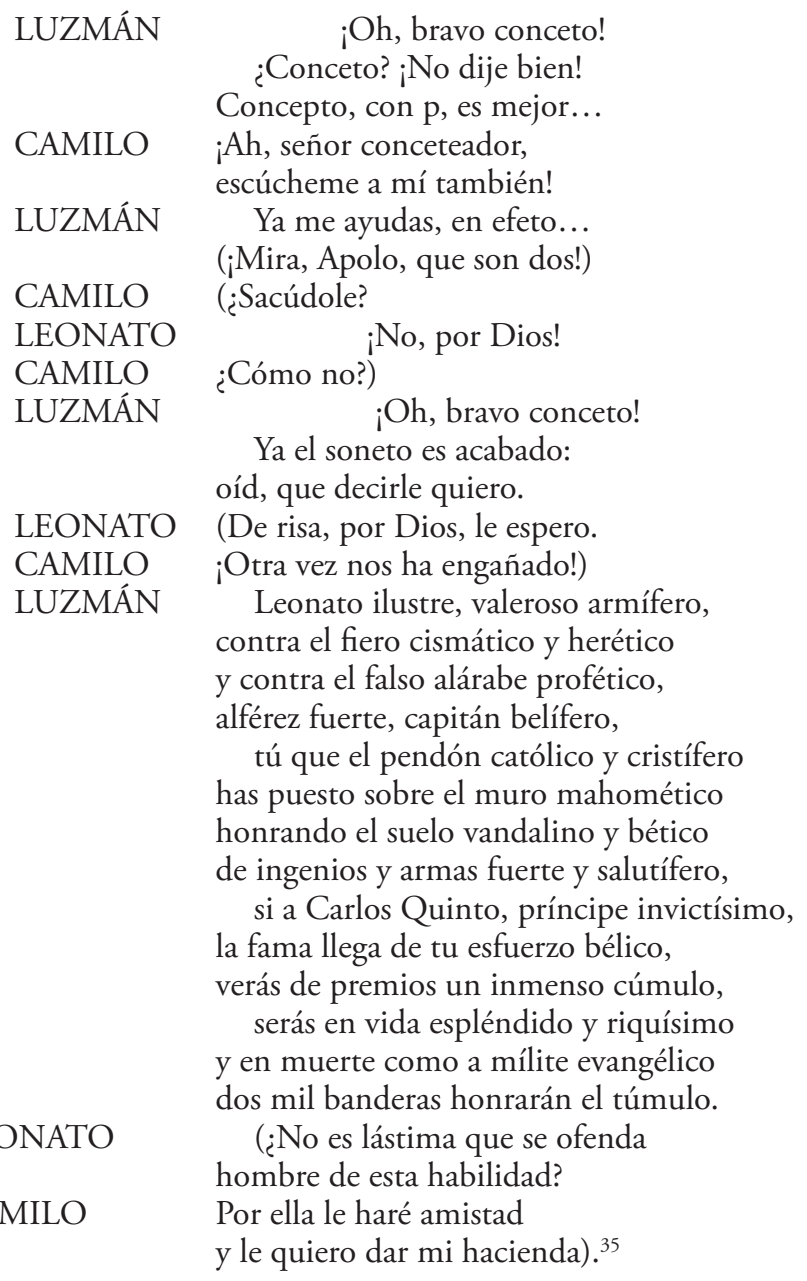

35. Lope de Vega, El caballero del milagro, vv. 2337-2367. 
En este caso, resulta significativo observar que algún fino estudioso ha defendido el carácter serio de este soneto. Discrepamos humildemente y entendemos que la lectura de este en su contexto, en la comedia, impide por completo esa interpretación; si además consideramos la posibilidad de la polémica antigongorina, esa lectura debe quedar, en principio, totalmente descartada. Pero sea como sea, el primer argumento es el más fuerte y nos lleva a confirmar lo que veníamos diciendo: no se deben descontextualizar estos textos para su correcta interpretación crítica. Están en conexión y bien motivados dentro de la comedia.

\section{Percepciones y adaptaciones desde el mundo de la escena}

No parece mal, encaminándonos ya al final de este trabajo, acabar con algunas reflexiones y percepciones, más allá de las nuestras propias, que podemos recabar entre los profesionales del mundo de la escena a la hora de enfrentarse a nuestro teatro del Siglo de Oro. El verso, la poesía y el interludio poético son retos que se les plantean ante los espectadores contemporáneos. Y desde luego, recalquémoslo, tanto por los directores como por el público, son percibidos, también, como poesía.

Decía a este propósito Cayetano Luca de Tena en 1953:

Nuestro teatro del Siglo de Oro exalta y depura la expresión poética, literaria, «extra-teatral», hasta un grado máximo. Calderón, Lope, Tirso, todos nuestros autores están llenos de elocuencia, de una exuberancia lírica que hace presumir que sería gustada — y hasta exigida - por el público de los corrales. Hoy, en cambio, sólo a trescientos años de distancia, el público no tolera que el diálogo se salga del estricto cauce que marca la acción teatral. Cualquier digresión, por brillante que ésta sea literariamente, impacienta al espectador normal y hace que los críticos —espectadores de selección - apliquen despectivamente a la obra epítetos como «discursiva», «literaturizante» $y$ «conversacional». ${ }^{36}$

La tesis doctoral recientemente defendida por Purificació Mascarell incluye un tesoro de inapreciable valor: todas sus inteligentes entrevistas con los distintos directores de la Compañía Nacional de Teatro Clásico. Según Rafael Pérez Sierra «Lope es la vida y la poesía. Y Calderón es el teatro y la construcción. Y los demás se sitúan por debajo, a una gran distancia», para añadir más tarde: «En esa época, el teatro se escribía en verso, pero se era o no se era poeta, que es muy diferente. Y, excepto Lope, ningún dramaturgo del XVII tiene poesía». Independientemente de nuestro posible grado de acuerdo, pasemos de nuevo a las dificultades que esa poesía entraña, en las que se centraba Luca de Tena e incide con términos muy sinceros y coloquiales en su entrevista José Luis Alonso de Santos:

36. Declaraciones citadas por César Oliva (2009: 230). 
es cierto que el verso y el lenguaje barroco no permiten una comunicación instantánea y adensan el mensaje. Pero el espectador de teatro clásico se 'autoprograma' antes de ver una obra. Si no, no lo aguantaría. La gente que va al teatro clásico tiene una paciencia de santo, porque está media hora sin entender una sola palabra y no pasa nada.

Y concluye: «Para disfrutar del teatro clásico y tratar de entenderlo se precisa de una actitud escogida voluntariamente por el espectador».

Frente a las reflexiones tan francas de José Luis Alonso de Santos, y en cierto modo también frente a lo que afirmaba Cayetano Luca de Tena, hay que decir que en múltiples puestas en escena actuales se percibe un gran acierto y sensibilidad. Se pueden recordar aquí fragmentos de El castigo sin venganza con la Fundación Siglo de Oro, de La vida es sueño y La verdad sospechosa o, por recordar títulos menos conocidos, y de Lope, La cortesía de España con la Joven Compañía Nacional de Teatro Clásico bajo la dirección de Josep Maria Mestres, con momentos de una fuerza lírica arrebatadora. El verso y la poesía no se deben percibir como un obstáculo, sino más bien al contrario, en ocasiones serán un trampolín para que la obra alcance las más altas cotas. Pero ciertamente existe una dificultad y un reto en el verso y en la poesía.

Para salvar esas distancias, esa brecha que se puede encontrar entre el texto clásico y el espectador, está, más allá de las capacidades del director de escena, ese mediador que es el adaptador o versionista. Pregunta Purificació Mascarell: "¿Dónde se encuentra el límite en la manipulación del texto a la hora de adaptarlo a la escena contemporánea y al gusto actual de los espectadores?», y a tal pregunta responde Eduardo Vasco:

Hay un límite que tiene que ver con el amor a la poesía barroca y con el amor a la dramaturgia. Una regla de oro sería: si vas a tener que transformar excesivamente un texto, a lo mejor no te interesa montarlo y es mejor hacer otra cosa. En los textos barrocos hay que respetar las estructuras versales, es decir, si una escena está construida en endechas tiene que respetarse, y si hay un soneto, lo mismo. Porque creo que mantenerlo es más bello, no por una cuestión de ortodoxia. Pero también hay que despojar los textos clásicos de hábitos e inmundicias relativos a la moda y los gustos del momento en que se escribieron. No se trata en absoluto de transformar el texto hasta el punto de traicionarlo. Más bien, la tendencia actual sería trabajar con el texto para limpiarlo, tratando de adaptarlo mínimamente a la escena contemporánea. ${ }^{37}$

En realidad la respuesta de Vasco suscita otra pregunta: ¿cuáles son los «hábitos e inmundicias relativos a la moda y los gustos del momento en que se escribieron»?

37. Todas las citas de las entrevistas proceden del cuarto capítulo de la tesis de Purificació Mascarell (2014: 415ss). 
En este sentido, tal vez precisamente los fragmentos poéticos que algunos pueden percibir como uno de esos pasajes donde el público se impacienta, porque no entiende o porque alargan la obra sin avanzar la acción, deban ser sometidos a especial consideración en función, precisamente, de su relevancia poética e histórica, canónica. Imaginemos un Castigo sin venganza sin la glosa de «sin mí, sin vos y sin Dios», o por recordar algo que ya ha sucedido, una Dama boba sin el baile «de dó viene el caballero». Tal vez en casos así el versionista y director deberían pensar si tales fragmentos conviene mantenerlos aunque solo sea porque forman parte de los standards que ya no solo el público de la época, sino incluso el público más formado que hoy acude al espectáculo, está esperando oír y disfrutar. Y si no es público formado, es parte de la poesía de la obra y, en tanto que uno de esos «morceaux de bravure» a que alude Pedraza (2011: 124n.), «uno de esos lugares canónicos de la poesía lopesca y aun de la propia española que se le debe hacer llegar» según Molanes y Candelas (2011: 82). Es parte de la razón, poética, por lo que esa obra se convirtió en clásico. Entendemos que esta reflexión, de carácter histórico, también debería tener su peso si queremos poner en escena el teatro clásico en la actualidad..$^{38}$

\section{Conclusiones}

Todas estas reflexiones que hemos hecho, con las premisas establecidas, argumentos defendidos y ejemplos aportados, entendemos que comportan algunas conclusiones de rango teórico y práctico.

Desde un punto de vista teórico es necesario entender, y es lo que queríamos defender con nuestra aportación y con nuestro recuerdo de Gitlitz y de otros estudiosos, que el teatro no es exclusivamente espectáculo, sino que lo es de manera plenamente compatible y simbiótica con la poesía y con la literatura. El teatro del Siglo de Oro es espectáculo, ciertamente, un espectáculo que adquiere todavía mayor rango gracias a la poesía que también — pero tampoco exclusivamente- lo conforma.

Otra consecuencia teórica, o podríamos decir historiográfica, es que no podemos ni conviene establecer o concebir barreras genéricas impermeables. Y no por la tan llevada y traída mixis o mezcla genérica, sino porque por su propia esencia el teatro del Siglo de Oro se concibe poéticamente, o bien es, con alta frecuencia, poesía desarrollada dramáticamente.

Desde un punto de vista práctico, lo que hemos dicho nos concierne. Nos concierne como editores del teatro de Lope. Como editores convendrá tener siempre presente la concepción poética del teatro, o de mucha parte del teatro, de

38. No se piense que la postura filológica es siempre más «arqueológica»; Pedraza, contrario a puestas en escena arqueológicas, lamenta la supresión del baile, y, por otro lado, Purificació Mascarell (2012) está más de acuerdo con la versión de Mayorga. 
Lope de Vega, pues siempre puede haber al acecho una canción desconocida y una técnica de glosa que Lope utilizaba y su público reconocía. Mucho más rápido que nosotros, filólogos, y que el público, general y medio, actual. Por eso, tendremos que estar especialmente atentos a la identificación de las posibles fuentes y a subrayar para el lector interludios o composiciones poéticas intercaladas.

Por su parte, los editores de poesía acaso tendrán que estar atentos a buscar las huellas del teatro, y abiertos al estudio omnicomprensivo de la poesía, a las manifestaciones poéticas en el teatro. Por poner un pequeñísimo y técnico ejemplo: presenta muchísimo interés el estudio comparado de la ortología en el teatro y la poesía de Lope. Es decir, en la poesía de Lope. En cuanto a las manifestaciones poéticas en el teatro, podemos citar ya un acierto: el de Antonio Carreño en su edición de las Rimas humanas y otros versos, que recogió también composiciones, como lo había hecho el propio Lope en su antología.

En tanto que historiadores de la literatura, la aceptación de esas barreras permeables también ha tenido ya algún buen ejemplo. Felipe Pedraza cerraba su monografía de 2003 sobre El universo poético de Lope de Vega con un capitulo «sobre la lírica en el teatro».

Pero como no nos debemos limitar a leer teatro, extraigamos también una última conclusión y consecuencia práctica de esta concepción sobre el teatro como poesía, no menos importante: y es que también, aunque no nos ataña a los filólogos, tal vez esta condición poética merecería ser tenida en cuenta en el mundo escénico en las labores de adaptación y puesta en escena, aunque sin duda ya lo es.

Estos podrían ser algunos caminos por los que convendría transitar y estos, entendemos, los puntos de partida, así como las conclusiones. No los olvidemos; o, para ser más justos y exactos, como mucho de lo que aquí se ha dicho ya lo dijeron García de Enterría, Umpierre, Gitlitz y Díez de Revenga, no volvamos a olvidarlos. 


\section{Bibliografía}

Alín, José María y María Begoña Barrio Alonso, El cancionero teatral de Lope de Vega, Londres, Tamesis, 1997.

Antonucci, Fausta, "Los sonetos amorosos en díptico de Lope de Vega», Arte nuevo, 4 (2017), 383-414.

Carballo Picazo, Alfredo (ed.), Alonso López Pinciano, Philosophía antigua poética, Madrid, CSIC, 1953, 3 vols.

Cervantes, Miguel de, Viaje del Parnaso y poesias sueltas, eds. J. Montero Reguera y F. Romo Feito, con la colaboración de M. Cuiñas Gómez, Madrid, Real Academia Española, 2016.

Cortés Hernández, Santiago, Literatura de cordel y teatro en España (16751825), Universidad de Alcalá, 2008, tesis doctoral publicada en web. 2905-2017, <http://pliegos.culturaspopulares.org/estudio.php>.

Di Pastena, Enrico (coord.), Comedias de Lope de Vega. Parte VII, Lérida, Milenio-Universitat Autònoma de Barcelona, 2008.

Díez de Revenga, Francisco Javier, Teatro de Lope de Vega y lírica tradicional, Murcia, Universidad de Murcia, 1983.

Dixon, Victor, "La intervención de Lope en la publicación de sus comedias», Anuario Lope de Vega, 2 (1996), 45-63.

Fernández Rodríguez, Daniel, «Lope de Vega y el género bizantino (novela y teatro): público, autopromoción y mercado editorial» (en prensa).

Fothergill-PaYne, Louise, «La doble historia de la alegoría (unas observaciones generales sobre el modo alegórico en la literatura del Siglo de Oro)», en Actas del Sexto Congreso Internacional de Hispanistas (Toronto, 22-26 de agosto de 1977), eds. A. M. Gordon y E. Rugg, Toronto, Department of Spanish and Portuguese, University of Toronto, 1980, 261-264. 28-052017, <http://cvc.cervantes.es/literatura/aih/indice.htm>.

García de Enterría, María Cruz, «Función de una letra para cantar en las comedias de Lope de Vega: comedia engendrada de una canción", Boletín de la Biblioteca Menéndez Pelayo, LI (1965), 3-62.

García Reidy, Alejandro, Las musas rameras. Oficio dramático y conciencia profesional en Lope de Vega, Madrid / Frankfurt am Main, Iberoamericana / Vervuert, 2013.

Gituitz, David M., La estructura lírica de la comedia de Lope de Vega, Valencia, Albatros ediciones / Hispanófila, 1980.

Gómez Sánchez-Ferrer, Guillermo, Del corral al papel. Estudio de impresores españoles de teatro en el siglo XVII, tesis doctoral defendida en la Universidad Complutense de Madrid, Madrid, 2015.

González, Silvia, "El éxito editorial de las relaciones de comedias y su alcance en la producción de Álvaro Cubillo de Aragón: estudio y aportaciones para un repertorio", en Dramaturgos y espacios teatrales andaluces de los siglos XVI-XVII. Actas de las XXVI Jornadas de Teatro del Siglo de Oro, coords. 
E. García-Lara y A. Serrano, Almería, Instituto de Estudios Almerienses, 2011, 411-426.

González Cañal, Rafael, "Las relaciones de comedias de Rojas Zorrilla», en Cuatro triunfos áureos y otros dramaturgos del Siglo de Oro, eds. A. González, S. González y L. von der Walde Moheno, México, D. F., El Colegio de México-Universidad Autónoma Metropolitana-AITENSO, 2010, 15-40.

Guillén, Claudio, El primer Siglo de Oro. Estudios sobre géneros y modelos, Barcelona, Crítica, 1988.

Hack, Viviana, «La batalla en el alma. El tipo de lucha en Psychomachia de Prudencio y sus raíces bíblicas», en Cristianismo y helenismo en la filosofía tardoantigua y medieval, ed. S. Filippi, Rosario (Argentina), Paideia Publicaciones, 2009, 61-70.

Hilborn, Harry W., «El creciente gongorismo en las comedias de Lope de Vega", en Homenaje a William L. Fichter: estudios sobre el teatro antiguo hispánico y otros ensayos, coords. A. David Kossoff y J. Amor y Vázquez, Madrid, Castalia, 1971, 281-294.

Laplana Gil, José Enrique (coord.), Comedias de Lope de Vega. Parte XII, Madrid, Gredos, 2013.

López Martínez, José Enrique (coord.), Comedias de Lope de Vega. Parte XIV, Madrid, Gredos, 2015.

López Pinciano, Alonso, Philosophía antigua poética, ed. A. Carballo Picazo, Madrid, CSIC, 1953, 3 vols.

Mascarell, Purificació, "Finea, Casandra y Belisa en el siglo XX. Actualizaciones de Lope de Vega por la CNTC», Don Galán. Revista de investigación teatral, 2 (2012). 03-03-2017, <http://teatro.es/contenidos/donGalan/ donGalanNum2/pagina.php?vol=2\&doc=2_8>.

- El Siglo de Oro español en la escena pública contemporánea. La Compañia Nacional de Teatro Clásico (1986-2011), tesis doctoral defendida en la Universitat de València, Valencia, 2014. 03-03-2017, <http://roderic.uv.es/ handle/10550/41097>.

Molanes Rial, Mónica y Manuel Ángel Candelas Colodrón, «Las adaptaciones lopescas de Juan Mayorga: La dama boba en el siglo XXI», Anuario Lope de Vega. Texto, literatura, cultura, 17 (2011), 66-84.

Montero Reguera, José y Fernando Romo Feito, con la colaboración de Macarena Cuiñas Gómez (eds.), Miguel de Cervantes, Viaje del Parnaso y poesías sueltas, Madrid, Real Academia Española, 2016.

NiETo, Raquel, La función dramática del soneto en las comedias sonetiles de Lope de Vega, Universidad de Castilla-La Mancha, 2010 [tesina].

Oliva, César, Versos y trazas: (un recorrido personal por la comedia española), Murcia, Editum (Ediciones de la Universidad de Murcia), 2009.

Pedraza Jiménez, Felipe B., El universo poético de Lope de Vega, Madrid, Ediciones del Laberinto, 2003. 
-, Drama, escena e historia. Notas para una filosofía del teatro, Granada, Universidad de Granada, 2005.

—, «La escenificación de los clásicos: de la trasgresión a la complicidad», en Espacios de representación y espacios representados en el teatro áureo español, ed. F. Sáez Raposo, Bellaterra, Prolope-Universitat Autònoma de Barcelona, 2011, 103-126.

—, "Notas y escolios al Arte nuevo de hacer comedias", en Lope de Vega, Arte nuevo de hacer comedias. Edición crítica. Fuentes y ecos latinos, eds. F. B. Pedraza Jiménez y P. Conde Parrado, Cuenca, Ediciones de la Universidad de Castilla-La Mancha, 2016, 101-635.

Pontón, Gonzalo, «Fortuna de unos versos de El perseguido», Anuario Lope de Vega. Texto, literatura, cultura, 19 (2013), 189-203.

—, «Imprenta y orígenes del teatro comercial en España (1560-1605)», Arte Nuevo, 4 (2017), 555-649.

Presotto, Marco, "Apuntes sobre el soneto 'La calidad elementar resiste' y $\mathrm{La}$ dama boba», Anuario Lope de Vega. Texto, literatura, cultura, 19 (2013), 204216.

Profeti, Maria Grazia, «Lope y las relaciones de sucesos», Revista de Literatura, 147 (2012), 139-163.

Quintero, María Cristina, Poetry as Play. Gongorismo and the comedia, Ámsterdam / Filadelfia, John Benjamins Publishing Company, 1991.

RaVASINI, Ines, «Pervivencia lírica, intertextualidad y función dramática en el teatro del Siglo de Oro", en Actas del IV Congreso Internacional de la Asociación Internacional Siglo de Oro (AISO) (Alcalá de Henares, 22-27 de julio de 1996), eds. M. Cruz García de Enterría y A. Cordón Mesa, Alcalá de Henares, Universidad de Alcalá, 1998, vol. II, 1295-1304.

Restrepo, Santiago, "Otra escaramuza más en la rivalidad temprana entre Lope y Góngora: el soneto esdrújulo de El caballero del milagro» (en prensa).

Rico, Francisco, Breve biblioteca de autores españoles, Barcelona, Seix Barral, 1990.

Riquer, Martín de, Los trovadores, Barcelona, Ariel, 1975.

Romanos, Melchora, "Solo uno en el mundo gongoriza', presencia del gongorismo en el teatro del Siglo de Oro", en Actas del XVI Congreso de la Asociación Internacional de Hispanistas: Nuevos caminos del hispanismo, coords. P. Civil y F. Crémoux, Madrid, Iberoamericana, 2010, vol. I, 75-98.

Samonà, Carmelo, Appunti ed esempi sull'esperienza culterana nel teatro di Lope e della sua scuola, Roma, De Santis, 1964.

SÁnchez Jiménez, Antonio (ed.), Lope de Vega, Arcadia, prosas y versos, Madrid, Cátedra, 2012.

Sánchez Laílla, Luis (coord.), Comedias de Lope de Vega. Parte XV, Madrid, Gredos, 2016.

Serés, Guillermo, «Argel fingido y renegado de amor'. Lope entre Garcilaso y Ariosto", Rilce, 23.1 (2007), 207-221. 
Serés, Guillermo (ed.), Lope de Vega, El Argel fingido y renegado de amor, en Comedias de Lope de Vega. Parte VIII, coord. R. Ramos, Lérida, MilenioUniversitat Autònoma de Barcelona, 2009, II, 575-721.

Ubersfeld, Anne, Semiótica teatral, Madrid, Murcia, Cátedra-Universidad de Murcia, 1989 [original Lire le Théâtre, 1977].

Umpierre, Gustavo, Songs in the Plays of Lope de Vega: A study of their dramatic function, Londres, Tamesis Books, 1975.

VALDÉs, Ramón, «Sátira y sátira menipea en la Comedia Nueva y el entremés de la primera mitad del siglo XVII», en Teatri del Mediterraneo. Riscritture e ricodificazioni tra '500 e '600, ed. V. Nider, Trento, Editrice Università degli Studi di Trento, 2004, 117-209.

Vega Carpio, Lope de, prólogo «El teatro» a las Comedias de Lope de Vega. Parte XII, ed. y coord. J. E. Laplana Gil, Madrid, Gredos, 2013, I, 57-59.

—, "Prólogo: El teatro a los lectores» a las Comedias de Lope de Vega. Parte XIV, ed. y coord. J. E. López Martínez, Madrid, Gredos, 2015, I, 72-79.

—, "Prólogo: El teatro a los lectores» a las Comedias de Lope de Vega. Parte XV, ed. y coord. L. Sánchez Laílla, Madrid, Gredos, 2016, I, 75-80.

—, "Prólogo dialogístico» a la Decimasexta parte de las comedias de Lope de Vega Carpio, Madrid, Viuda de Alonso Martín a costa de Alonso Pérez, 1621. Ejemplar consultado: BNE, R 13867.

-, El amante agradecido, eds. O. Sanz y M. D. Gómez Martín y coords. R. Valdés y M. Morrás, en Comedias de Lope de Vega. Parte X, Lérida, Milenio-Universitat Autònoma de Barcelona, 2010, II, 631-767.

—, La Arcadia, ed. A. M. Porteiro Chouciño, en Comedias de Lope de Vega. Parte XIII, coord. N. Fernández Rodríguez, Madrid, Gredos, 2014, I, 47-230.

—, El Argel fingido y renegado de amor, ed. G. Serés y coord. R. Ramos, en Comedias de Lope de Vega. Parte VIII, Lérida, Milenio-Universitat Autònoma de Barcelona, 2009, II, 575-721.

—, La batalla del honor, ed. R. Valdés y coords. V. Pineda y G. Pontón, en Comedias de Lope de Vega. Parte VI, Lérida, Milenio-Universitat Autònoma de Barcelona, 2005, I, 65-292.

—, El caballero de Olmedo, ed. F. Rico, Madrid, Cátedra, 1983.

-, El caballero del milagro, eds. S. Restrepo y R. Valdés, y coord. L. Sánchez Laílla, en Comedias de Lope de Vega. Parte XV, Madrid, Gredos, 2016, II, 971-1153.

-, Lo cierto por lo dudoso, ed. S. Vuelta, Reichenberger, Kassel, en prensa.

-, Decimasexta parte de las comedias de Lope de Vega Carpio, Madrid, viuda de Alonso Martín, a costa de Alonso Pérez, 1621. Ejemplar consultado: BNE, R 13867.

—, La gallarda toledana, ed. D. Fernández Rodríguez y coord. J. E. López Martínez, en Comedias de Lope de Vega. Parte XIV, Madrid, Gredos, 2015, I, 415-581.

—, El maestro de danzar, ed. D. Fernández Rodríguez, en Lope de Vega, El maestro de danzar. La creación del mundo, Madrid, Gredos, 2012, 11-258. 
—, La octava maravilla, eds. R. Valdés y M. Nogués y coords. R. Valdés y M. Morrás, en Comedias de Lope de Vega. Parte X, Lérida, Milenio-Universitat Autònoma de Barcelona, 2010, II, 891-1041.

-, La vengadora de las mujeres, ed. E. Di Pastena y coord. L. Sánchez Laílla, en Comedias de Lope de Vega. Parte XV, Madrid, Gredos, 2016, I, 391-534.

-, Viuda, casada y doncella, eds. R. S. Feit y D. McGrady y coord. E. Di Pastena, en Comedias de Lope de Vega. Parte VII, Lérida, Milenio-Universitat Autònoma de Barcelona, 2008, III, 1097-1240.

Vega García-Luengos, Germán, «Sobre la identidad de las partes de comedias», Criticón, 108 (2010), 57-78.

Vélez de Guevara, Luis, El Diablo Cojuelo, ed. R. Valdés, estudio preliminar de B. Perinán, Barcelona, Crítica, 1999. 